\title{
Population densities of the Black-faced Cotinga Conioptilon mcilhennyi in south-east Peru
}

HUW LLOYD

\begin{abstract}
Summary
Population densities of the near-threatened Black-faced Cotinga Conioptilon mcilhennyi were investigated during a 21-month survey of lowland rainforest bird communities in Madre de Dios, south-east Peru. Surveys for the species were conducted at two locations along the Río Madre de Dios. C. mcilhennyi is more abundant in old floodplain/seasonally flooded swamp forest mosaic habitat than in seasonally flooded swamp forest. Regional population estimates along the Río Madre de Dios, Río Parramanu and Río de las Piedras range from 1,153 to 2,178 individuals. Current threats to this species and its habitat are discussed along with several conservation recommendations, including the proposal that the newly designated Parc Nacional Bahuaja-Sonene or existing Zona Reservada de Tambopata-Candamo are expanded to encompass suitable Black-faced Cotinga habitat.
\end{abstract}

\section{Introduction}

The Black-faced Cotinga Conioptilon mcilhennyi is a near-threatened arboreal frugivore confined to the lowland forests of south-east Peru and extreme western Brazil (Terborgh et al. 1990, Collar et al. 1994, Whittaker and Oren in press). This highly vocal and monotypic genus was until recently known only from one site (Balta) in southern Ucayali (Lowery and O'Neil 1966) and a very small number of sites in Madre de Dios (Ridgely and Tudor 1994). Other recent records of C. mcilhennyi are from along the Río Caimisea (Alto Urubamba), in Department of Cuzco (B. Walker pers. comm., G. Angehr pers. comm.). In Madre de Dios, the Black-faced Cotinga has been recorded along the Río Manu at the Estación Biológica Cocha Cashu (Terborgh et al. 1990) with sightings of the species continuing to the mouth of the river but it appears to be absent from upriver of Boca Manu (B. Walker pers. comm.). There are also no confirmed reports of this species south of the Río Madre de Dios, which probably represents the southern limit of its small distribution and thus explaining its absence from the nearby Zona Reservada de Tambopata-Candamo (see Ridgely and Tudor 1994). In 1996 it was recorded at two locations on the upper and central Río Tejo and Río Juruá, near Taumaturgo, Acre, in extreme western Brazil (Whittaker and Oren in press). J. Minns (pers. comm.) also recorded the species at Lago Ceara, on the Río Juruá, in 1998.

Where found, the species is reportedly fairly common in the subcanopy of river-edge forest habitat, swampy or seasonally flooded forest habitats, and along 
lake or river margins at elevations up to $350 \mathrm{~m}$, rarely to 450m (Collar et al. 1992, 1994, Ridgely and Tudor 1994). However, G. Angehr (pers. comm.) recorded this species at $700 \mathrm{~m}$ elevation along the Río Caimisea in 1997, but Whittaker and Oren (in press) did not record it toward $800 \mathrm{~m}$ elevation near the crest of the Serra do Divisor. These last two authors recorded the species along streamside habitat and at the edge of clearings, but more importantly also in the canopy of terra firme forest some $4 \mathrm{~km}$ from the Río Juruá, a forest type from which it is reportedly absent (Ridgely and Tudor 1994). J. Minns (pers. comm.) recorded this species in "transitional forest" around tree-fall gaps within $2 \mathrm{~km}$ of the Río Juruá.

Although some of the lowland forest habitats in Madre de Dios, south-east Peru are relatively intact, e.g. the upper Río Manu is protected by Manu National Park (Kratter 1995a), the region has recently been subject to some selective logging, while other areas of Madre de Dios are being opened up for development schemes, such as oil/gas extraction, road construction, human colonization, agriculture, ecotourism and gold mining (Collar et al.1994, Kratter 1995b). Currently the forest habitats in close proximity to all the main river tributaries in Madre de Dios are among the most threatened habitats in south-east Peru (Phillips et al. 1994).

In this paper I examine the population densities of the Black-faced Cotinga in two forest habitat types at two locations along the lower Río Madre de Dios in south-east Peru and calculate regional population estimates for the species.

\section{Study sites}

The research was conducted between January 1997 and September 1998. The following descriptions of the study sites are summarized from Lloyd and Palomino (in press). Forest habitats were classified using the system derived by Phillips (1993), and tested by Nicholson and Edwards (1994).

\section{EcoAmazonia Lodge}

EcoAmazonia (EA) is an ecotourist lodge situated on the north bank of the lower region of the Río Madre de Dios ( $12^{\circ} 31^{\prime} \mathrm{S}, 68^{\circ} 55^{\prime} \mathrm{W}$; elevation $205 \mathrm{~m}$ ) approximately $28 \mathrm{~km}$ east of the frontier town of Puerto Maldonado (Figure 1). The lodge is located north of the Parc Nacional Bahuaja-Sonene, and some three hours travel west of the Bolivian frontier. The principle habitat at the EA is primary seasonally flooded swamp forest characterized by an abundance of tree palms, e.g. Scheelea buytyracea, Euterpe precatoria and Socratea exorrhiza. Broad-leaved tree species occur at low frequency. The canopy is normally less than $20 \mathrm{~m}$ and broken, with a dense understorey of shrubs and small palms. Vines and scandent herbs are moderately abundant but large lianas are rare. Ground vegetation is restricted to drier areas atop low hummocks.

\section{Cuzco Amazonico Reserve}

The Cuzco Amazonico Reserve (CA) is also situated on the north bank of the Río Madre de Dios (Figure 1), approximately $15 \mathrm{~km}$ east of Puerto Maldonado 


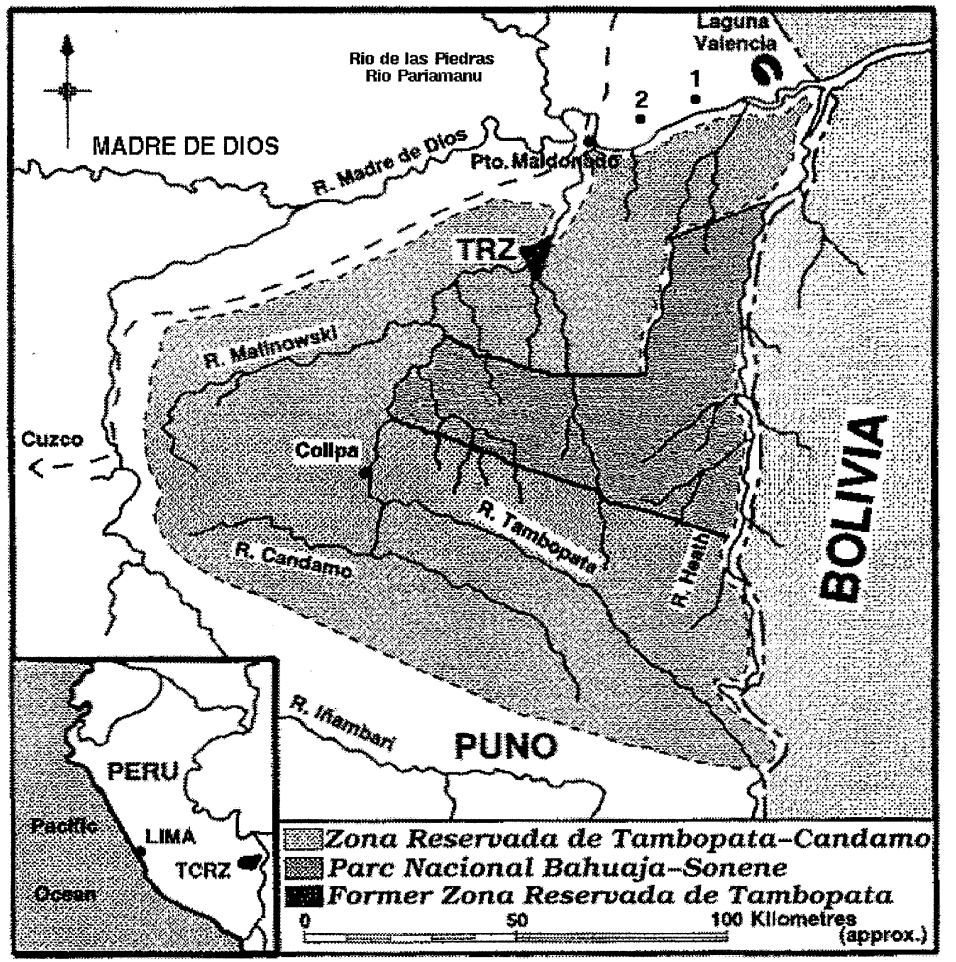

Figure 1. Approximate location of both study sites and the newly established Parc Nacional Bahuaja-Sonene. 1, EcoAmazonia Lodge; 2, Cuzco Amazonico Reserve.

$\left(12^{\circ} 32^{\prime} \mathrm{S}, 69^{\circ} 3^{\prime} \mathrm{W}\right.$; elevation $\left.210 \mathrm{~m}\right)$. This lodge has been established as an ecotourist and research reserve since 1977 (Davies et al. 1991). The predominant forest type at CA is a mosaic of old floodplain forest with seasonally flooded swamp forest. The canopy is tall $(>30 \mathrm{~m})$ and more continuous than seasonally flooded swamp forest. The palm Iriartea deltoidea is particularly abundant in this forest type. Large emergent trees are common. The understorey is relatively open owing to the dense shade cast by the more closed canopy. The fern Adiantum latifolium dominates the ground vegetation.

\section{Methods}

\section{Bird census}

Bird censuses were conducted using the variable circular plot (VCP) method (Reynolds et al. 1980). A total of 63 census stations were established along 12 transects. EA had 39 census stations located along six transects in seasonally flooded swamp forest, while 24 stations were established along six transects in old floodplain/seasonally flooded swamp forest at CA. All transects were located within $5 \mathrm{~km}$ of the river's edge. Census stations were located $200 \mathrm{~m}$ apart, while transects were also located at a minimal distance of $200 \mathrm{~m}$ apart. Transects were established either perpendicularly across existing trails, along existing trails, or 
in areas where there were no trail systems. Transects located perpendicularly across trails had a central census station placed directly on the trail, with the remainder of the transect continuing $400 \mathrm{~m}$ either side of the trail. The number of census stations and length of each transect were dependent on the amount of available habitat at each site.

During January and September of each year, VCP surveys began at 05h3o and were concluded by $08 \mathrm{~h} 30$, after which time vocal activity decreased significantly. During September-December first light occurs earlier in the morning. Thus VCP surveys had to begin at $04 \mathrm{~h} 45$ in order to census adequately birds that sing during the predawn chorus (Terborgh et al. 1990). Two observers spent 10 minutes at each census station recording all bird contacts. These contacts were assigned to one of three categories; seen, heard or seen and heard. Observers noted the time of the contact, species, and the number of individuals. Observers then estimated horizontal distance from the centre of the census station to each individual contact. Finally each bird contact was assigned to one of five height categories: 1 , ground level (<1 m); 2, understorey ( $1-5 \mathrm{~m}) ; 3$, mid-canopy (5-15 m); 4, canopy; 5, flying above the canopy.

A total of six repeat surveys (each survey lasting 18 days) was made at EA while five repeat surveys were made at $\mathrm{CA}$, the number at each site being determined by the permission of the lodge owners. Two repeats of each transect were made per visit to each site. The direction of the surveys along each transect was rotated to counter the bias of bird activity and the time of day. Distance data were then analysed using the program DISTANCE version 3.5 (Thomas et al. 1998).

An estimation of the total area of suitable forest habitat in the region was made from a Landsat satellite image of the region (Earth Observation Satellite Company 1991, Foster et al. 1994, Kratter 1995b). The satellite image covers approximately $12^{\circ} 15^{\prime}-13^{\circ} 32^{\prime} \mathrm{S}$ and $68^{\circ} 10^{\prime}-69^{\circ} 40^{\prime} \mathrm{W}$ of lowland south-east Peru (Departments of Madre de Dios and Puno) and northern Bolivia (Kratter 1995b).

\section{Results}

\section{Population densities}

A total of 44 individual birds was recorded on circular plots. C. mcilhennyi was often recorded with other frugivores including Cobalt-winged Parakeets Brotogeris cyanoptera, Plumbeous Pigeon Columba plumbea, Black-spotted Barbet Capito niger and Purple-throated Fruitcrow Querula purpurata. Outside VCP sampling, the species was regularly encountered foraging in pairs or in groups of up to six individuals. At EA the species was often seen foraging with mixed-species flocks at the forest edge of the lodge clearing, perched and plucking fruits from Pourouma spp. Pairs were also observed roosting in the subcanopy of large broadleaved trees from 16 hoo. Pairs would call consistently to one another once they had landed in the subcanopy, and would begin several minutes of allo-preening before settling down (Lloyd and Palomino in press).

Population density estimates are shown in Table 1 . The density estimate for the forest habitat at CA is almost twice that for the species in the forest at EA. The overall population estimates correspond to the region portrayed from the 
Table 1. Population density of Conioptilon mcilhennyi in both forest habitats

\begin{tabular}{|c|c|c|c|c|}
\hline Location & Forest habitat & $\begin{array}{l}\text { Density (no. } \\
\text { individuals / } \\
\mathrm{km}^{2} \text { ) }\end{array}$ & $\mathrm{SD}$ & $\begin{array}{l}\text { Total population } \\
\text { estimate for region } \\
\text { (no. individuals) }^{a}\end{array}$ \\
\hline EcoAmazonia & $\begin{array}{l}\text { Seasonally flooded } \\
\text { swamp forest }\end{array}$ & 0.9 & \pm 1.0 & 1,153 \\
\hline $\begin{array}{l}\text { Cuzco } \\
\text { Amazonico }\end{array}$ & $\begin{array}{l}\text { Old floodplain/ } \\
\text { seasonally flooded } \\
\text { swamp forest }\end{array}$ & 1.7 & \pm 1.0 & 2,178 \\
\hline
\end{tabular}

a Total population size was calculated from the amount of available forest habitat, estimated from a Landsat satellite image of lowland south-east Peru and adjacent north-west Bolivia (Earth Observation Satellite Company 1991, Foster et al. 1994, Kratter, 1995b). Total area of available forest habitat estimated as $1,278 \mathrm{~km}^{2}$.

satellite image. Areas of suitable forest are distinguishable from the Landsat image as areas of diffuse purplish green (Hill and Foody 1994, Nicholson and Edwards 1994). From this image, and assuming that the species is not found on the south bank and beyond on the Río Madre de Dios, the total amount of available habitat in the region was estimated as $1,278 \mathrm{~km}^{2}$ (along three major rivers; Ríos Madre de Dios, de las Piedras and Parramanu). The overall population estimates for $C$. mcilhennyi are therefore expressed as a range using the two local density estimates as minimum and maximum values (Table 1).

\section{Discussion}

Conioptilon mcilhennyi occurs at low population densities in lowland forest habitat and at higher population density in old floodplain/seasonally flooded swamp forest mosaic, compared with seasonally flooded swamp forest habitats. The density estimates for both locations are thought to be reasonably accurate for two reasons. First, the SD for each estimate is relatively small (Table 1). Second, the estimates are comparable to those calculated by Terborgh et al. (1990) in the only other bird census to calculate absolute densities for bird species in lowland rainforest habitat in Peru. Using spot-mapping methodology, an estimate of one individual per square kilometre of "mature floodplain forest" was obtained from a census of a 97 ha plot at the Estación Biológica Cocha Cashu (Terborgh et al. 1990). The study also emphasized the restricted habitat occupancy of the species, since it was recorded in just 10\% of the 97 ha plot (Terborgh et al. 1990).

The population estimate for the species in the region (Table 1 ) is likely to be too low because I have assumed that the species is not found south of the Río Madre de Dios. Recently, however, there has been an unconfirmed record for the species found in "varzea" forest at Lago Sandoval $\left(12^{\circ} 37^{\prime} \mathrm{S}, 69^{\circ} 5^{\prime} \mathrm{W}\right)$ situated 20 $\mathrm{km}$ east of Puerto Maldonado and $3 \mathrm{~km}$ south-east of the river (P. Champlin pers. comm.).

Robinson and Terborgh (1995) suggested that interspecific competition with Querula purpurata restricts C. mcilhennyi to the early end of a primary successional gradient generated by the meandering action of white-water rivers at Estación Biológica Cocha Cashu, in Parc Nacional Manu. During 21 months of surveys I 
saw no aggressive interactions between these two species. In fact, Q. purpurata is more abundant at these two locations (density estimate for $\mathrm{EA}=11.9 \pm 6.4$; $\mathrm{CA}=$ $17.8 \pm 8.9)$ than in three other forest types found within the nearby ZRTC (middle/upper floodplain forest $=4.7 \pm 0.4$; old floodplain forest $=5.1 \pm 39.1$; terra firme sandy-clay forest $=7.6 \pm 1.8$; H.L. unpubl. data). C. mcilhennyi is often referred to as an "edge" species (Terborgh et al. 1990) or as a river-edge habitat indicator species (Stotz et al. 1996) because it has often been located in river-edge forest (corresponding to lower floodplain forest, using Phillips's (1993) forest classification scheme), or at the edge of clearings and around tree-falls. The results of this study and other recent sightings confirm that the Black-faced Cotinga appears not to be a river-edge species or even an edge species but in fact a seasonally flooded swamp/floodplain forest species that can occasionally be found in edge habitats, tree-falls or in terra firme forests up to $5 \mathrm{~km}$ from major rivers.

\section{Current threats to the Black-faced Cotinga}

All known sightings of Black-faced Cotinga have been made within $4^{-5} \mathrm{~km}$ of the river's edge. Currently the species is classified as Near-threatened by Collar et al. (1994) and Vulnerable by Stotz et al. (1996) since its habitat is the most threatened forest type in the region (Phillips et al. 1994). From the Landsat satellite image, suitable forest habitat totalling $1,278 \mathrm{~km}^{2}$ can be identified along the Ríos Madre de Dios, de las Piedras and Parramanu, extending to approximately $10 \mathrm{~km}$ at most from the rivers' edge. Although suitable habitat can be identified along all three rivers, currently no populations of this species have been found along the Río de las Piedras or Río Parramanu.

Along the Río Madre de Dios, the greatest pressure on this species's habitat is human colonization, since the human population in and around the Puerto Maldonado area continues to expand (Kratter 1995b). Most development in the region occurs along rivers (Foster et al. 1994) and it is probable that the amount of available habitat shown on the Landsat image of the region has been reduced in the years since the image was acquired. Currently there are $c .700-1,000$ people living along the Río Madre de Dios from Puerto Maldonado east to EA including the area around Lago Sandoval (C. Kirkby pers. comm.).

Small-scale logging operations such as those along the lower Río de las Piedras also pose a major threat to this species. Logging operations currently can proceed to more than $20 \mathrm{~km}$ inland from the river's edge (C. Kirkby pers. comm.). This places any cotinga population at great risk. Normally these logging operations, which have been under way since the 1960s, target four important timber species, mahogany Sweitenia spp., Spanish Cedar Cedrela spp., cedromacho Cedrelinga spp. and ishpingo Amburana spp., all of which are more characteristic of middle, upper and old floodplain forests, and terra firme sandy-clay forests. C. mcilhennyi is more abundant in floodplain forest mosaics with primary seasonally flooded swamp forests bordering the rivers. It is not found in areas of low scrubby secondary growth with dense vines and lianas, typical of highly disturbed areas (pers. obs.). This suggests that the species cannot tolerate high levels of logging such as those currently under way in the lower Río de las Piedras region, which has currently lost all of its mahogany trees and 90\% of Spanish cedar (C. Kirkby pers. comm.). 
Of the 12 tree species most important to mestizo people of the region, six are palms (Phillips et al. 1994). The importance of seasonally flooded swamp forests to local people will probably increase in years to come given the moderate abundance of palms and its proximity to the river's edge, in comparison to the terra firme sandy-clay forests (Phillips et al. 1994). This would further increase the pressure on the Black-faced Cotinga.

\section{Conservation}

Effective measures must be taken to preserve both floodplain and seasonally flooded swamp forests, which are considered globally significant cornerstone habitats (Stotz et al. 1996), and the bird communities they hold. Part of the Blackfaced Cotinga's range has already been protected within Parc Nacional Manu. The nearby Zona Reservada de Tambopata-Candamo (currently being reviewed for territorial zoning) or the newly created Parc Nacional Bahuaja-Sonene (PNBS) should be expanded to incorporate the floodplain of the Río Madre de Dios, from (and including) the location of EA, east to the frontier with Bolivia, and extending some $10 \mathrm{~km}$ inland on both the north and south banks of the river (Figure 1 ). Families that have settled in this region, e.g. the Lago Valencia community, must be allowed to remain in the area and encouraged to play an active role in its conservation. This would help conserve suitable habitat not only for the Blackfaced Cotinga, but also a full complement of river-edge and flooded-forest bird species, including other threatened species such as the Rufous-fronted Antthrush Formicarius rufifrons which has also recently been found at the site (Lloyd and Palomino in press).

The conservation of the CA reserve poses a different problem. Recent research has shown that the bird community and the habitat here are disturbed (Lloyd and Palomino in press). The lodge itself is in the process of reconstruction, which already threatens two newly discovered territories of F. rufifrons (Lloyd and Palomino in press). I do not advocate the inclusion of this Reserve within an expanded ZRTC or PNBS on the basis of its bird community, or on the basis of the high population density of $C$. mcilhennyi here, or because of the conservation status of one or two other threatened bird species found at this site (see Lloyd and Palomino in press). Probably the most sensible reason for the inclusion of the CA reserve within an expanded ZRTC would be its importance for long-term tropical botanical studies from established 1 ha permanent plots (Phillips et al. 1998).

Following these measures suitable habitat along all the major rivers in the region must be identified. Rapid and urgent surveys are required, with priority given to surveys along the Río de la Piedras (along with the establishment of a protected area in the headwaters), Río Parramanu and the Río Tahuamanu, since logging concessions for the remainder of this area are to be sold off in the near future (C. Kirkby pers. comm.).

\section{Acknowledgements}

I would like to thank Arturo Palomino Marin, Juan Carlos Oyola Ponce, Alexi Nunez and John Hazelmyer for helping to establish the research sites and coordinate the bird research for Proyecto Tambopata. My greatest thanks go to the many volunteers on Proyecto Tam- 
bopata from around the world who made the project possible by helping to collect the data and contributing financially to the research. I would like to thank the coordinators of Proyecto Tambopata: C. Kirkby, T. Doan, A. Palomino, A. Cornejo and J. Wattling. They gave continued support and assistance throughout the duration of my research in south-east Peru. Barry Walker, of Manu Expeditions, generously provided equipment for the project and much information regarding the distribution of the Black-faced Cotinga in Madre de Dios. I would also like to thank the responsible officials in both INRENA and the Peruvian Ministry of Agriculture for permission to conduct the research in Tambopata. Many sponsors supported the research and sincere thanks go to the Grand Circle Foundation, Lindeth Charitable Trust, Albert Reckitt Trust, Dr Andrew Lloyd, the AngloPeruvian Society and the Tambopata Reserve Society.

\section{References}

Collar, N. J., Gonzaga, L. P., Krabbe, N., Madrono Nieto, A., Naranjo, L. G., Parker III, T. A. and Wege, D. C. (1992) Threatened birds of the Americas. The ICBP/IUCN red data book. Part 2. Cambridge, U.K.: International Council for Bird Preservation and International Union for Conservation of Natural Resources.

Collar, N. J., Crosby, M. J. and Stattersfield, A. J. (1994) Birds to watch 2: the world list of threatened birds. Cambridge, U.K.: BirdLife International (BirdLife Conservation Series 4).

Davies, T. J., Fox, C., Salinas, L., Ballon, G. and Arana, C. (1991) Annotated checklist of the birds of Cuzco Amazonico, Peru. Occas. Pap. Mus. Nat. Hist. (University of Kansas) 144: 1-19.

Earth Observation Satellite Company (1991) Landsat thematic mapper scene 432981356410809. Path 002, row 069. Colour bands 3, 4, 5. Image date: 27 July 1991. Lanham, Maryland, USA.

Foster, R. B., Parker III, T. A., Gentry, A. H., Emmons, L. H., Chicchon, A., Schulenberg, T., Rodrieguez, L., Lamas, G., Ortega, H., Icochea, J., Wust, W., Rono, M., Castillo, J. A., Phillips, O. L., Reynel, C., Kratter, A., Donahue, P. K. and Barkley, L. J. (1994) The Tambopata-Candamo Reserve Zone of south-eastern Peru: a biological assessment. Washington, D.C.: Conservation International (RAP working papers 6).

Hill, R. A. and Foody, G. M. (1994) Separability of tropical rain-forest types in the Tambopata-Candamo Reserved Zone, Peru. Int. J. Remote Sensing 15: 2687-2693.

Kratter, A. W. (1995a) Status, habitat and conservation of the Rufous-fronted Antthrush, Formicarius rufifrons. Bird Conserv. Internatn. 5: 391-404.

Kratter, A. W. (1995b) Bamboo specialisation in Amazonian birds. PhD dissertation, Louisiana State University, Baton Rouge, Louisiana.

Lloyd, H. and Palomino, A. (in press) Bird communities of five ecotourist locations in the Tambopata province, Madre de Dios, south-east Peru. In C. A. Kirkby, T. M. Doan, H. Lloyd, A. Cornejo, W. Arizabal and A. Palomino, eds. Tourism development and the status of Neotropical lowland wildlife in Tambopata, southeastern Peru: recommendations for tourism and conservation. London: Tambopata Reserve Society (TReeS).

Lowery, G. H. and O'Neil, J. P. (1966) A new genus and species of cotinga from eastern Peru. Auk 83: 1-9.

Nicholson, B. and Edwards, J. (1994) Forest Classification Project: section A - vegetation analysis and ground truthing. In Report of the TReeS Tambopata-Candamo Expedition: a biological survey in the Tambopata-Candamo Reserve Zone, south-east Peru. London: Tambopata Reserve Society.

Phillips, O. L. (1993) Comparative valuation of tropical forests in Amazonian Peru. PhD dissertation, Washington University, St Louis, Missouri. 
Phillips, O. L., Gentry, A. H., Reynel, C., Wilkin, P. and Glavez-Durand, B. C. (1994) Quantitative ethnobotany and Amazonian conservation. Conserv. Biol. 8: 225-248.

Phillips, O. L., Malhi, Y., Higuchi, N., Laurance, W. F., Nunez, P., Vasquez, M. R., Laurance, S. G., Ferriera, L. V., Stern, M., Brown, S. and Grace, J. (1998) Changes in the carbon balance of tropical forests: evidence from long-term plots. Science 282: 439-442.

Reynolds, R. T., Scott, J. M. and Nussbaum, R. A. (1980) A variable circular plot method for estimating bird numbers. Condor 82: 309-313.

Ridgely, R. and Tudor, G. (1994) The birds of South America. II. The suboscine passerines. Austin, Texas: University of Texas Press.

Robinson, S. K. and Terborgh, J. (1995) Interspecific aggression and habitat selection by Amazonian birds. J. Anim. Ecol. 64: 1-11.

Stotz, D. F., Fitzpatrick, J. W., Parker, T. A. III and Moskovits, D. K. (1996) Neotropical birds: ecology and conservation. Chicago: University of Chicago Press.

Terborg, J. W., Robinson, S. K., Parker, T. A. III, Munn, C. A. and Pierpont, N. (1990) The structure and organisation of an Amazonian forest bird community. Ecol. Monogr. 60: 213-328.

Thomas, L., Laake, J. L., Derry, J. F., Buckland, S. T., Borchers, D. L., Marques, F., Pollard, J. H. and Fewster, R. M. (1998) DISTANCE 3.5. University of St Andrews, U.K.: Research Unit for Wildlife Population Assessment.

Whittaker, A. and Oren, D. (in press) Important ornithological records from the Rio Juruá, western Amazonia, including twelve additions to the Brazilian avifauna. Bull. Br. Orn. Club.

HUW LLOYD

TReeS-RAMOS, Casilla 28, Puerto Maldonado, Madre de Dios, Peru.

Current address: 17 Longford Road, Chorlton, Manchester M20 9WP, U.K. e-mail huw_l@hotmail.com 
